\title{
Determination of Quality Parameters of Honey from Taraba State - Nigeria
}

\author{
Tanko Bako ${ }^{1}$, Ezekiel Ambo Mamai ${ }^{2}$, Boman James Bature ${ }^{3}$ \\ ${ }^{1}$ Department of Agricultural and Environmental Engineering, University of Agriculture, Makurdi, Nigeria \\ ${ }^{2}$ Department of Soil Science and Land Resource Management, Federal University, Wukari, Nigeria \\ ${ }^{3}$ Department of Agricultural and Bio-Environmental Engineering, Nuhu Bamalli Polytechnic, Zaria, Nigeria
}

Email address:

engbako@gmail.com (T. Bako)

\section{To cite this article:}

Tanko Bako, Ezekiel Ambo Mamai, Boman James Bature. Determination of Quality Parameters of Honey from Taraba State - Nigeria. Chemical and Biomolecular Engineering. Vol. 4, No. 1, 2019, pp. 1-9. doi: 10.11648/j.cbe.20190401.11

Received: September 8, 2018; Accepted: September 30, 2018; Published: May 7, 2019

\begin{abstract}
The aim of this study is to evaluate the quality parameters of honey samplescollected from different locations in Taraba State, in terms of physicochemical properties such as colour, specific gravity, refractive index, viscosity, moisture content, ash content, free acidity, lactone acidity, total acidity, $\mathrm{pH}$ value, electrical conductivity, sugar content, hydroxymethylfurfural (HMF) content, diastase activity and protein content. The results showed that mean values of honey temperature ranges from $29.4 \pm 0.49$ to $38.5 \pm 0.27^{\circ} \mathrm{C}$; colour, light amber to dark amber; specific gravity, $1.30 \pm 0.01$ to $1.48 \pm 0.01$; refractive index, $1.47 \pm 0.01$ to $1.50 \pm 0.02$; viscosity, $23.2 \pm 0.10$ to $34.2 \pm 0.10$ Pas; moisture content, $11.27 \pm 0.01$ to $19.70 \pm 0.01 \%$; ash content, $0.14 \pm 0.01$ to $0.52 \pm 0.04 \%$; free acidity, $14.86 \pm 0.03$ to $32.74 \pm 0.01 \mathrm{meqkg}^{-1}$; lactone acidity, $1.58 \pm 0.01$ to $3.71 \pm 0.03 \mathrm{meqkg}^{-1}$; total acidity, $16.44 \pm 0.03$ to $35.52 \pm 0.01 \mathrm{meqkg}^{-1} ; \mathrm{pH}$ value, $3.67 \pm 0.02$ to $5.10 \pm 0.19$; electrical conductivity, $0.08 \pm 0.01$ to $0.48 \pm 0.02 \mathrm{mScm}^{-1}$; total reducing sugar content, $74.30 \pm 0.03$ to $82.30 \pm 0.04 \%$; sucrose content, $3.58 \pm 0.02$ to $4.71 \pm 0.02 \%$; hydroxymethylfurfural (HMF) content, $10.51 \pm 0.04$ to $14.31 \pm 0.02 \mathrm{mgkg}^{-1}$; diastase activity, $23.20 \pm 0.02$ to $26.46 \pm 0.02 \mathrm{G}^{\circ}$ and protein content, $0.74 \pm 0.01$ to $0.85 \pm 0.01 \%$. The quality parameters were subjected to a one way ANOVA at $\mathrm{p} \leq 0.05$. There were significant differences in the colour, specific gravity, viscosity, moisture content, ash content, free acidity, lactone acidity, total acidity, $\mathrm{pH}$ value and electrical conductivity of the honey samples while refractive index, sugar content, hydroxymethylfurfural (HMF) content, diastase activity and protein content showed no significant differences. A 2-tailed F-LSD test at 5\% level of significance shows that the differences between the mean values are statistically significant for all the locations for temperature, viscosity, moisture content, free acidity, lactone acidity, total acidity and electrical conductivity of the honey samples while colour, specific gravity and ash content shows that the differences between themean values are statistically significant for most of the sample locations. The honey samples present a good level of quality because the physicochemical values were in the range of approved limits (conforming to codex standards) for all honey samples. It was indicated that honey from the area will be suitable for exportation when processed appropriately.
\end{abstract}

Keywords: Honey, Physicochemical Properties, Quality Parameters, Taraba State

\section{Introduction}

Honey is a natural substance produced by bees, mainly ApismelliferaL. [1] and is a nutritious food of economic importance worldwide. Codex Alimentarius [2] defined honey asa naturally sweet substance produced by honey bees, Apismellifera, from plants' nectar or from the secretions of living parts of plants or excretions of plant sucking insects on the living parts of plants, which honey bees collect, transform by combining with specific substances of their own, deposit, dehydrate, store and leave in the honey comb to ripen and mature. According to James et al. [3] the bees produce honey to serve as their source of food during scarcity or in times of adverse weather conditions. Natural honey is one of the products most widely hunted for due to its unique nutritional and medicinal properties, which are accredited or ascribed to the influence of the different groups of substances it contains. Honey has long being consumed by humans. It is used in various foods and beverages as a sweetener and flavoring 
agent. Honey has antioxidant and antimicrobial properties. It also has a role in religion and symbolism [4].

Essentially, natural honey is a sticky and viscous solution with a content of $80-85 \%$ carbohydrate (mainly glucose and fructose), $15-17 \%$ water, $0.1-0.4 \%$ protein, $0.2 \%$ ash and minor quantities of amino acids, enzymes, minerals, pollen grains, pigments and vitamins as well as other substances like phenolic compounds [3, 5-7]. Jameset al. [3] stated that each of these minor elements is known to have uniquenutritional or medicinal properties and the exclusive blend accounts for the varied and different applications of natural honeys. Although the major elements of honey are nearly the same in all honey samples, the precise chemical composition and physical properties of natural honeys vary according to the plant species on which the bees forage $[3,8]$. Furthermore, differences in climatic conditions, soil characteristics, honey bee specie, environmental temperature, harvesting methodsand storage conditions, among others are important factors that can affect the various properties of honey [9-12].

Honey can be characterized according to its geographical origin [7]. It has been reported that honey samples showed regional variation in the physic-chemical parameters such as $\mathrm{pH}$, enzymes activities, ash contents, electrical conductivity and hydroxymethylfurfural (HMF) [13]. The variations in honey colors are entirely due to different plant sources and form a continuous range from pale yellow through amber to a darkish red to black. The darkening of honey may be due to change in heat or temperature [14]. Honey has the tendency to form granules, due to which make it different from other sweeteners. In its compositions, sugars are the main components of its dry matter. The physical properties of honeys such as high density, high viscosity and immunity from spoilage are due to concentrated solution of sugars [15].

More than 22 sugars have been found in honey but dextrose and laevulose are the major components. Most of these sugars are more complex than monosaccharides. Ten disaccharides have been identified includes maltose, sucrose, maltulose, turanose, isomaltose, laminaribiose, nigerose, kojibiose, gentiobiose and $B$-trehalose. The trisaccharides are also found consist of maltotriose, erlose, melezitose, centose 3-a5 isomaltosyl glucose, 1-kestose, isomaltotriose, panose, isopanose and theanderose. All these sugars are present in very small quantities [16].

Many organic acids are also present in honey. These are lactic, formic, butyric, tartaric, pyruvic, acetic, citric, oxalic, succinic, malic, maleic, a-ketoglutaric G- 6- phosphate, pyroglutamic, glycolic and gluconic acids etc. Among these the major one is gluconic acid. It produces from the action of an enzyme glucose oxidase on the dextrose [17]. The presence of enzymes in honey is a unique characteristic that present it different from all other sweetening agents. These enzymes originate from the yeasts, pollen, bee, nectar and micro-organisms present in the honey. Enzymes are complex protein materials that under mild conditions bring about chemical changes. Some of the most important honey enzymes are acid phosphatase, diastase, glucose oxidase, catalase and invertase. Heating of honey can be weakened or destroyed all these enzymes [16, 17].

According to Bogdanov et al. [18] honey contains varying amounts of mineral substances ranging from 0.02 to $1.03 \mathrm{~g} / 100 \mathrm{~g}$. The physicochemical parameters have great importance to the honey for industry. These constituents such as minerals, moisture content, reducing sugars, electrical conductivity, free acidity, sucrose content and HMF have influence on nutritional quality, granulation, the storage quality, flavor and texture of the honey. The medicinal value of honeys is also due to these constituents. Therefore, the International Honey Commission (IHC) has proposed certain constituents as quality criteria for honey [16].

Honey has a long history of use as an effective medicine since ancient civilization for a wide range of disease conditions [19]. Keeping in view the importance of honey the present study was therefore aimed to evaluate quality parameters of honey samples collected from different areas of Taraba State.

\section{Materialsand Methods}

\subsection{Sample Collection and Preparation}

The honey samples were purchased from different honey sellers from various locations inTaraba state of Nigeria namely; Zing, Yorro, Jalingo, Gashaka, Kurmi, Sarduna, Takum, Donga andUssa. All the samples were collected fresh in sterile containers (dully labeled with numbers, place and date of collection). Unwanted material such as wax sticks, dead bees and particles of combs were removed by straining the samples through cheesecloth before analysis. All honey samples weighing between 100 and $250 \mathrm{~g}$ were subsequently stored at $-20{ }^{\circ} \mathrm{C}$ to prevent any possible matrix alteration (fermentation phenomena) and analyzed at the earliest in such a waythat none of the sample exceeded the storage period of 1 month. The samples were thawed at room temperature before the analyses wereperformed.

\subsection{Experimental Design}

The experimental design for the statistical analysis follows a one-treatment effect (nine sample locations) in a Completely Randomized Design (CRD) involving a one-way classification with three replications per experimental unit giving twenty seven (27) observations for the experiment.

\subsection{Quality Analyses of Honey Samples}

The physicochemical properties of the honey samples were determined to assess its quality and purity. The quality indices which were used to determine the quality of the honey samples are the colour, specific gravity, refractive index, viscosity, moisture content, ash content, free acidity, lactone acidity, total acidity, $\mathrm{pH}$ value, electrical conductivity, sugar content, hydroxymethylfufural (HMF), diastase activity and protein content. The experiments were replicated three times.

Color determination: Color determination was carried out using a color comparator (Lovibond 2000 visual comparator). 
Clear blanks were placed in compartments 1, 3, 5 of the comparator. The honey sample was also placed in compartment 2 or 4 of comparator. The comparator was held at a convenient distance of 20 to $30 \mathrm{cmfrom}$ the eye and viewed by diffused light (daylight fluorescent lamp). The sample was moved from compartment to compartment until the sample equals the match standard [20].

Determination of specific gravity: The specific gravity of honey was determined as the ratio of the mass of honey to the mass of an equal volume of water. The density of the honey was determined using the density bottle. A25mL densitybottle was cleaned, dried and weighed $\left(\mathrm{W}_{0}\right)$ and then filled with the honey sample, stopper inserted and reweighed to give $\left(\mathrm{W}_{1}\right)$. The bottle was emptied, washed, dried and was substituted with distilled water and weighed to give $\left(\mathrm{W}_{2}\right)$. The specific gravity (Sp.gr) was calculated from the expression [20].

$$
\text { Sp. gr }=\frac{\text { Mass of the substance }}{\text { Mass of an equal volume of water }}=\frac{W_{1}-W_{0}}{W_{2}-W_{0}}
$$

Determination of refractive index: Refractometer was used in this determination. Few drops of the sample were transferred into the glass slide of the refractometer. Water at $30^{\circ} \mathrm{C}$ was circulated round the glass slide to keep its temperature uniform. Through the eyepiece of the refractometer, the dark portion viewed was adjusted to be in line with the intersection of the cross. At no parallax error, the pointer on the scale pointed to the refractive index [20].

Determination of viscosity: A clean, dried viscometer with a flow time above 200 seconds for the oil to be tested was used. The sample was filtered through a sintered glass (fine mesh screen) to eliminate dust and other solid material in the oil sample. The viscosity meter was filled with the sample by inverting the tube's thinner arm into the honey sample and suction force was drawn up to the upper timing mark of the viscometer, after which the instrument was turned to its normal vertical position. The viscometer was placed into a holder and inserted to a constant temperature bath set at $29^{\circ} \mathrm{C}$ and allowed approximately 10 minutes for the sample to come to the bath temperature at $29^{\circ} \mathrm{C}$. The suction force was then applied to the thinner arm to draw the sample slightly above the upper timing mark. The afflux time by timing the flow of the sample as it flowed freely from the upper timing mark to the lower timing mark was recorded [20].

Determination of moisture content: The moisture content was determined according to AOAC [20]. In this regard, the sample materials were taken in a flat-bottom dish (preweighed) and kept overnight in an oven at $100-110^{\circ} \mathrm{C}$ and weighed. The loss in weight was regarded as a measure of moisture content which was calculated by the following formula:

\footnotetext{
Moisture (\%) $=\frac{\text { Weight of fresh sample }- \text { Weight of dry sample }}{\text { Weight of fresh sample }} \times 100$
}

Determination of ash content: For determination of ash content, the method of AOAC [20] was followed. According to the method, $10 \mathrm{~g}$ of each sample was weighed in a silica crucible. The crucible was heated in a muffle furnace for about 3 to $5 \mathrm{~h}$ at $500^{\circ} \mathrm{C}$. It was cooled in desiccators and weighed. To ensure completion of ashing, it was reheated again in the furnace for half an hour more, cooled and weighed. This was repeated consequently till the weight became constant (ash became white or grayish white). Weight of ash gave the ash content and was calculated by the following formula:

$$
\text { Ash }(\%)=\frac{\text { Weight of sample after ashing }}{\text { Weight of fresh sample taken }} \times 100
$$

Determination of acidity: Acidity was measured by titration method. First $0.05 \mathrm{~N} \mathrm{NaOH}$ was added drop by drop to honey solution, titration is stopped when $\mathrm{pH} 8.5$ is achieved (free acidity), instantly $10 \mathrm{ml} 0.05 \mathrm{~N} \mathrm{NaOH}$ was added, and without interval back-titration was done with $0.05 \mathrm{~N}$ HCL until $\mathrm{pH} 8.3$ is achieved (lactone acidity). Total acidity was calculated by adding free plus lactone acidities [20]. Results were expressed in meqkg ${ }^{-1}$.

Determination of $\mathrm{pH}$ : For determination of $\mathrm{pH}$ in the honey, the method of AOAC [20] was adopted and digital $\mathrm{pH}$ meter (HANNA instruments HI 96107 model, made in Italy) was used. The $\mathrm{pH}$ meter was calibrated with buffers at $\mathrm{pH}$ 4and 10. Sample solution containing $20 \mathrm{~g}$ of honey in $75 \mathrm{~mL}$ of de-ionized water was taken in the beaker and the electrode of the $\mathrm{pH}$ meter was inserted in the solution and the $\mathrm{pH}$ value was read and recorded. When the first reading was completed, the electrode was washed with distilled water and dried-up with tissue paper. Similarly, as a continue series, all other samples were determined accordingly.

Determination of electrical conductivity: This was determined by measuring $20 \mathrm{~g}$ of honey and dissolved in $100 \mathrm{~mL}$ of distilled water mixed thoroughly to form solution. Electrical conductivity meter (HANNA instrument USA made in Romania. HI 98129) was immersed. The instrument was calibrated using potassium chloride $(\mathrm{KCl})$ dissolved in water (de-ionized) and made up to $1 \mathrm{~L}$ to be used as the standard reference solution [20]. The readings were recorded.

Determination of sugars

Determination of sugars (total sugar, reducing sugar and non-reducing sugar) was carried out using the Layne-Enyon method as described in AOAC [20]. About $5 \mathrm{~g}$ of honey sample was taken into a beaker and $100 \mathrm{ml}$ of warm water was added to it. The solution was stirred until all the soluble matters were dissolved and filtered through Whatman filter paper into a 250 volumetric flask. $100 \mathrm{ml}$ of the solution was pipetted and prepared into a conical flask, after which $10 \mathrm{ml}$ of diluted hydrogen chloride $(\mathrm{HCl})$ was added and boiled for 5 min. On cooling, the solution was neutralized to phenolphthalein with $10 \% \mathrm{NaOH}$ and kept in a 250 volumetric flask. This solution was used for titration against Fehling's solution and the reading was calculated as follows: 


$$
\begin{aligned}
& \text { Total sugar }(\%)=\frac{\text { Factor }(4.95) \times \text { dilution }(250) \times 2.5}{\text { Titre } \times \text { weight of sample } \times 10} \\
& \text { Reducing sugar }(\%)=\frac{\text { Factor }(4.95) \times \text { dilution }(250)}{\text { Titre } \times \text { weight of sample } \times 10}
\end{aligned}
$$

Non-reducing sugar was estimated as the difference between the total sugar content and reducing sugar content on subtraction (total sugar-reducing sugar).

Hydroxymethylfufural: Hydroxymethylfufural was determined by dissolving $10 \mathrm{~g}$ of unheated honey sample in $20 \mathrm{~mL}$ of cold distilled water. The solution was transferred into a $50 \mathrm{~mL}$ volumetric flask and made up to the mark. Into each of two test tubes, was added $2.0 \mathrm{~mL}$ honey solution and $5.0 \mathrm{~mL}$ P-toluidine solution. One milliliter of water (blank) was immediately added to one of the tubes and $1 \mathrm{~mL}$ of the barbituric acid solution to the other. The absorbance of the sample was measured against the blank solution in a $1 \mathrm{~cm}$ cell at $550 \mathrm{~nm}$ as soon as the maximum value was reached. For the calibration, a standard solution of $0.300 \mu \mathrm{g}$ of HMF spectrophotometrically assayed at $284 \mathrm{~nm}$ was used. Results were expressed as $\mathrm{mg} \mathrm{kg}^{-1}$ [20].

Diastase activity: Diastase activity was measured using a buffered solution of soluble starch and honey which was incubated in a specially designated glass tube, shaped to end in an inverted "V", in a thermostatic bath until the end-point was determined photometrically. Results were expressed (as Gothe degrees) as $\mathrm{mL}$ of $1 \%$ starch hydrolyzed by an enzyme in $1 \mathrm{~g}$ honey in $1 \mathrm{~h} \mathrm{[20]}$.

Protein content: The method is a version of the original Kjeldahl method. About $5 \mathrm{~g}$ of honey sample was mixed with potassium sulphate $\left(\mathrm{K}_{2} \mathrm{SO}_{4}\right)$ and a little of copper sulphate $\left(\mathrm{CuSO}_{4}\right)$ as a catalyst and digested in a long necked Kjeldhal bottles with concentrated sulphuric acid for approximately 2 hours. Distilled water was then added. The Kjeldahl bottle was placed in Kjeltec auto sampler 1035/30 systemwhere the ammonia was distilled into boric acid and the acid was simultaneously titrated with diluted sulphuric acid. A complete blank determination using only a piece of filter paper instead of the honey was carried through [20]. Nitrogen content is calculated by:

$$
\mathrm{N}(\%)=\frac{0.7\left(\mathrm{~V}_{1}-\mathrm{V}_{0}\right)}{\mathrm{M}}
$$

Where;

$\mathrm{V}_{1}=$ Mean volume in $\mathrm{ml}$ of $0.1 \mathrm{M}$ sulphuric required for honey,

$\mathrm{V}_{0}=$ Mean volume in $\mathrm{ml}$ of $0.1 \mathrm{M}$ sulphuric required for blank,

$\mathrm{M}=$ Weight in grams of the portion taken of the sample.

Protein content is calculated as $\mathrm{N} \times$ 6.25. Results are expressed as percentage of wet weight.

\subsection{Data Analysis}

Two computer packages, Microsoft Excel and Minitab 16 for windows were used in the statistical analysis. Statistical differences between honey samplesfrom different locations were tested by Analysis of Variance (ANOVA) at $\mathrm{p} \leq 0.05$. When significant difference was observed, treatment means were separated using the F-LSD.

\section{Results}

Mean values of honey quality parameters from nine locations of Taraba State are shown in Table 1.

Table 1. Mean Values of Honey Quality Parameters.

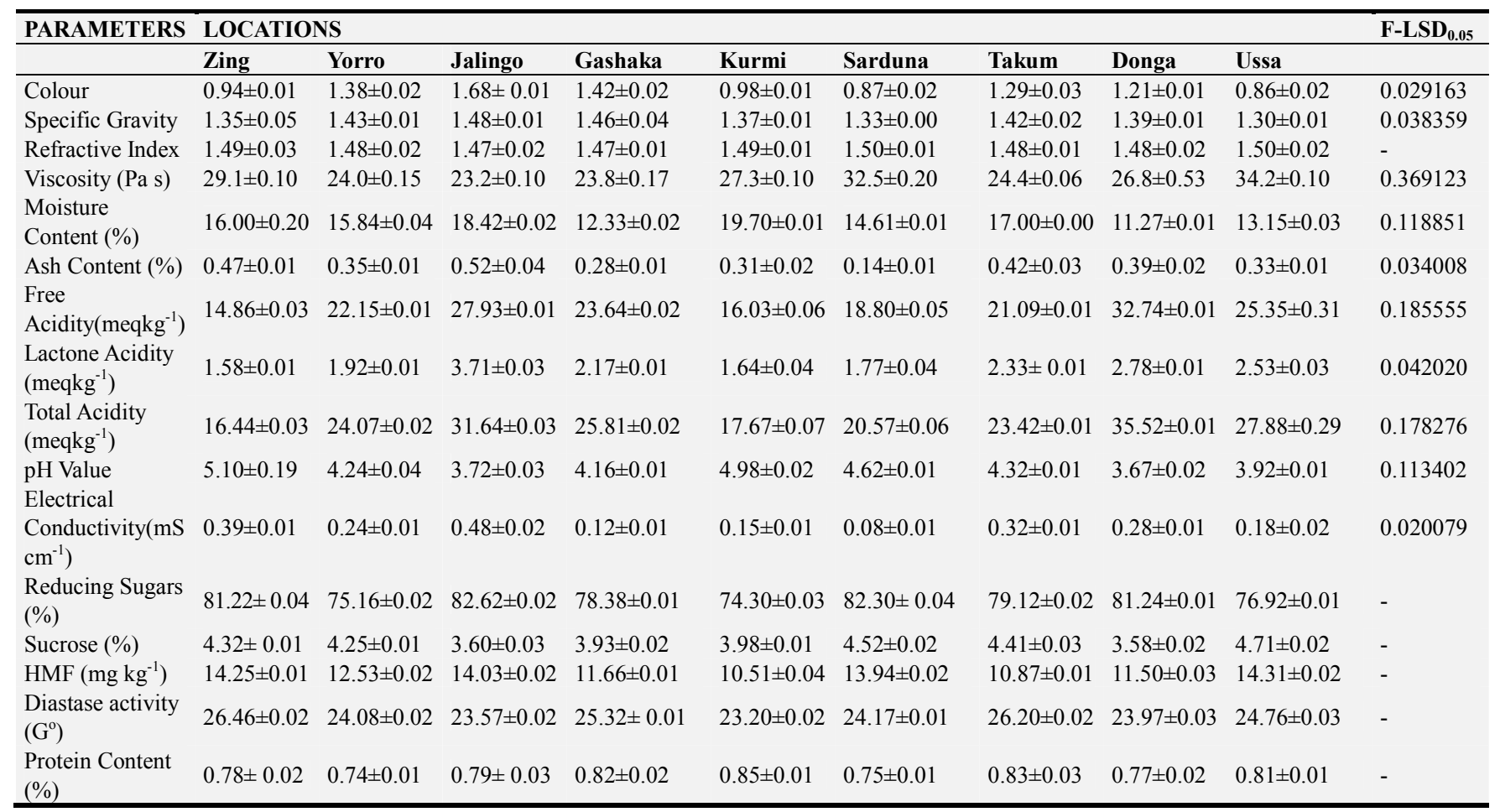




\section{Discussion}

Colour: The results of the physicochemical analysis revealed that the colour of the honey samples varied from light amber to dark amber. The mean values of the colour of honey samples analyzed ranged from $0.86 \pm 0.02$ to $1.68 \pm$ 0.01 . The samples having higher values appear brighter and the samples having lower values appear darker. From the ANOVA there was a significant difference $(p \leq 0.05)$ in the colour of honey samples obtained from the study area. A 2tailed F-LSD test at 5\% level of significance shows that the differences between the honey colours are statistically significant for all the locations except Sarduna versus Ussa which is not statistically significant. Honey colour is very important in determination of its commercial use and market value. Darker honeys are most often put to industrial use while the lighter colour honeys are marketed directly for consumption. Color plays a vital role in acceptability of product as it is the major characteristic property observed by the consumer. However, little is known about consumer color acceptability of honey. Bogdanov et al. [18] reported that in Germany, Austria and Switzerland dark color honeys have more consumer acceptability. According to Downey et al. [21] dark golden color is more preferred by Irish peoples. The color of honey is one of the most variable attributes and it depends upon botanical origin, along with other factors like ash content, temperature and time of storage as well as the presence of antioxidant pigments like flavonoids and carotenoids [22, 23].

Specific gravity: Most of the honey samples had acceptable levels of specific gravity at $27^{\circ} \mathrm{C}$ (i.e.>1.35). The mean specific gravity values obtained from the experiment ranged from $1.30 \pm 0.01$ to $1.48 \pm 0.01$. The values obtained are in conformity with the findings of Kamal et al. [24], Ouchemoukh et al. [25] and Basavarajappa et al. [26], that the specific gravity values of multifloral and unifloral honeys varies from 1.35 to 1.37 and 1.40 to 1.42 , respectively. From the ANOVA there was a significant difference $(p \leq 0.05)$ in the specific gravity of honey samples obtained from the study area. Significant difference $(\mathrm{p} \leq 0.05)$ was observed among most of the honey samples from the means separation. The variation in the specific gravity might be due to variation in the chemical composition [27]. The specific gravity property of honey has not been legislated by the European legislation [28].

Refractive index: The refractive index of the honey sample analyzed falls within the range of $1.47 \pm 0.01$ to $1.50 \pm 0.02$. The refractive index value obtained is similar to those reported by Adebiyi et al. [29]. The refractive index could be used to determine the level of adulteration and hence quality, based on the specification [29]. The refractive index of the honey samples are approximately the same and fall within the range of the codex standard of $1.4000-1.9000$ [2]. No significant difference $(p \leq 0.05)$ was observed among the honey samples.

Viscosity: The viscosity of the analyzed honey ranged from $23.2 \pm 0.10$ to $34.2 \pm 0.10$ Pas. From the ANOVA there was a significant difference $(p \leq 0.05)$ in the viscosity of honey samples obtained from the study area. A 2-tailed FLSD test at $5 \%$ level of significance shows that the differences between the viscosities of the honey samples are statistically significant for all the sample locations. The viscosity values of the study area were lower than the values (56.26 and 41.17 $\mathrm{Pa} \mathrm{s}$, 49.69 $\mathrm{Pa} \mathrm{s}, 37.89 \mathrm{~Pa} \mathrm{~s}$ ) reported by Oladipupo and Isah [30], who investigated in honey samples from Kachia, Gidan-Waya, Anchau in Kaduna State, respectively. Honey samples with high viscosity are described as a high quality honey. Viscosity is one of the physicochemical parameter used to measure the quality of the honey sample. The high viscosity of honey is one of the properties of honey that maintains its antimicrobial activity. Pure honey has a high viscosity [15]. The high viscosity values obtained in this work is an indication that the honey had not been diluted with other products. Honey consists of sugars mostly glucose and fructose.

Moisture content: The moisture content is the most essential quality component of honey, because the rate of fermentation, its shelf life span and processing characteristics are greatly determined by the amount of moisture content [31]. Moisture content affects the storage life of honey. Higher moisture contents can result in unwanted honey fermentation during storage period, due to the action of osmotolerant yeasts, which result in development of carbon dioxide and ethanol. Ethanol is further oxidized to acetic acid thus resulting in a sour taste [32]. The different moisture content of honey depends on harvesting season, the degree of maturity that honey reached in the hive, type of hive used, environmental temperature and moisture content of original plant $[33,34]$. Moisture content of honey can naturally be as low as $13 \%$ or as high as $23 \%$ depending on the source of the honey, climatic conditions and other factors [35]. In areas of high humidity, it can be difficult to produce honey of sufficient low water content [35]. To keep moisture content acceptable for export standard combs with more than $75 \%$ of the honey cells sealed should be harvested. High moisture content could accelerate crystallization in certain types of honey and increases its water activity of the honey to ferment and deteriorate its quality $[35,36]$. Moisture content of honey samples obtained varies between $11.27 \pm 0.01$ to $19.70 \pm$ $0.01 \%$. Significant difference $(\mathrm{p} \leq 0.05)$ was observed among all the honey samples. The Codex Alimentarius [2] standard specified moisture content of not more than $20 \%$ in honey for safety against fermentation caused by the action of osmotolerant yeasts during storage. One of the major criteria that determine the shelf stability of honey is its moisture content [37]. Hence the lower the moisture, the lower the probability that honey will ferment upon storage by osmotolerant yeasts [38]. One of the key indicators of honey adulteration is high level of moisture in the honey [39].

Ash content: Ash content is a reflection of the total mineral content of honey. It is an essential component of food which contains catalyst required for various body functioning 
reactions to sustain good health. The average ash content from the study ranged from $0.14 \pm 0.01$ to $0.52 \pm 0.04 \%$. This variability in ash content could be explained by the floral source of the honey, soil conditions, atmospheric conditions and physiology of each plant [7]. From the ANOVA there was a significant difference $(\mathrm{p} \leq 0.05)$ in the ash content of honey samples obtained from the study area. Significant difference $(p \leq 0.05)$ was observed among most of the honey samples from the means separation. Generally, the ash content of blossom honey is $\leq 6.0 \mathrm{~g} \mathrm{~kg}^{-1}(\leq 0.6 \%)$ as compared to honeydew honey where this value is $\geq 12.0 \mathrm{~g}$ $\mathrm{kg}^{-1}(\geq 1.2 \%$ ) [25]. Thus based on this standard, the honeys analyzed in this work are classified as blossom honey. Several investigations have shown that the ash content of honey depends mainly on the botanical origin of honey; i.e. light blossom honeys have low contents than dark honeys such as honeydew, chestnut and heather honeys [7]. The percentage ash content in honey is an important quality index which shows the mineral content of honey [40]. In this study, honey samples from all the studied areas had mean of ash value $(\%)$ below the maximum limit recommendedand thus in agreement with the international regulatory standards for quality honey [18].

Free acidity: In general, honey is acidic in nature irrespective of its origin and this is due to the presence of organic acids and inorganic ions. It is a useful criterion for evaluation of honey fermentation, authentication of unifloral honeys and for differentiating nectar from honeydew honeys [41]. Acidity in honey is due to the occurrence of organic acids in honey, predominantly gluconic acid [42]. The average free acidity of the analyzed honey ranged from $14.86 \pm 0.03$ to $32.74 \pm 0.01 \mathrm{meqkg}^{-1}$. Significant difference ( $p$ $\leq 0.05)$ in the free acidity values of honey from different locations was also observed. The results obtained from the study for free acidity shows that none of the samples analyzed exceeded the limit of $40 \mathrm{meq} \mathrm{kg}^{-1}$ established by the international regulations [18], all the samples analyzed conform to the international regulatory standards for quality honey. Bogdanov et al. [18] stated that honey is naturally an acidic substance with $\mathrm{pH}$ varying from 3.7 to 4.5 for blossom honey and from 4.5 to 6.5 for honeydew honey, regardless of the geographical origin. However, differences in acidity of honey may be as a result of the botanical origin or harvesting in different seasons.

Lactone acidity: The analyzed honey samples in the study showed lactone acidity values ranged between $1.58 \pm 0.01$ and $3.71 \pm 0.03 \mathrm{meqkg}^{-1}$. From the ANOVA there was a significant difference $(\mathrm{p} \leq 0.05)$ in the lactone acidity of honey samples obtained from the study area. A 2-tailed FLSD test at 5\% level of significance shows that the differences between the lactone acidity of the honey samples are statistically significant for all the sample locations.

Total acidity of honey: Codex Alimentarius specify that total acidity of honey should not be more than 50 meq $\mathrm{kg}^{-1}$ [2]. The overall average acidity of honey samples analyzed in this study ranged from $16.44 \pm 0.03$ to $35.52 \pm 0.01 \mathrm{meqkg}^{-1}$ which is acceptable range in the world honey market [2]. The mean values of acidity observed for all the samples were less than the maximum limit of $50 \mathrm{meq} \mathrm{kg}^{-1}$, which suggests that there was no undesirable fermentation in the honey samples. Significant difference $(\mathrm{p} \leq 0.05)$ was observed in the total acidity values of honey from different locations.All of the samples met the requirement of international standards, which indicates the freshness of honey samples and absence of unwanted honey fermentation. The acidity of the honey improves its antioxidant activity, contributes to flavor, and effects against the action of microorganisms. Variations in total acidity depend upon the floral source and harvest season. This study also reveals that the free acidity predominates over the lactone acidity in all the samples analyzed; similar observations were previously reported by other scientists $[8,24,43]$. This may be due to the hydrolysis of lactones which in turn increases free acids. The acid content of honey is relatively low, but it is an important factor for the honey taste. Most of the honey acids are added by the bees; the main honey acid is gluconic acid, which is a product of glucose oxidation by the enzyme glucose oxidase. The gluconic acid is, however, present as its own internal ester, which is a lactone and it does not contribute to honey's active acidity [44]. Several organic acids including formic acid, acetic acid, citric acid, lactic acid, maleic acid, malic acid, oxalic acid, pyeoyhtamic acid and succinic acid have been found in minor quantities in honey [44]. On the whole, the acids of honey account for less than 0.5 percent of the solids, but this level contributes to the flavour and is also partly responsible for the excellent stability of honey against microorganisms [8].

$\mathrm{pH}$ value: Honey $\mathrm{pH}$ which is indeed a useful index of possible microbial growth, is due to the presence of organic acids, mainly gluconic acid, pyruvic acid, maleic acid and citric acid in balance with corresponding lactones or their internal esters and inorganic ions like phosphate, sulfate and chloride [45]. Honey $\mathrm{pH}$ can provide a good indication of its botanical origin and it can also be used for the prediction of honey degradation during storage. The $\mathrm{pH}$ of blossom honeys generally varies between 3.2 and 4.6, with chestnut honey being an exception in having relatively high $\mathrm{pH}$ values of 5.0 to 6.0. Honeydew honeys have high $\mathrm{pH}$ values varying between 4.5 and 6.5 , due mainly to the fact that their mineral contents are higher than floral honey [45]. Honey is a buffer and, therefore, its $\mathrm{pH}$ does not change by the addition of small quantities of acids or bases. The buffer capacity of honey is due to the content of phosphate, carbonate and other mineral salts [44]. This parameter is of great importance during the extraction and storage of honey as it influences the texture, stability and shelf life of honey [42]. All studied honey samples were acidic in nature, and the $\mathrm{pH}$ values varied from $3.67 \pm 0.02$ to5.10 \pm 0.19 which agree with the $\mathrm{pH}$ of 2.25-5.84 found by other researchers [42, 46, 47]. The $\mathrm{pH}$ values were also within the acceptable range of between 3.6 and 5.6 [29]. Significant difference $(\mathrm{p} \leq 0.05)$ in the $\mathrm{pH}$ value was observed among most of the honey samples. The acidic $\mathrm{pH}$ of honey might be due to the constituent acids, mainly gluconic acid and minerals. The significance of $\mathrm{pH}$ at acidic 
range in foods cannot be overemphasized. They prevent the honey samples from constant infection by various species of micro-organisms and thus help to ensure constant shelf life for the honey samples. The $\mathrm{pH}$ values of honey are of great importance during storage, since the acidity can influence the texture, stability and shelf life of honey [9]. The acidic $\mathrm{pH}$ of all honey samples from various locations indicates they have good shelf life.

Electrical conductivity: The analyzed honey samples in the study showed electrical conductivity values ranged from $0.08 \pm 0.01$ to $0.48 \pm 0.02 \mathrm{mScm}^{-1}$. Significant difference ( $\mathrm{p} \leq$ 0.05 ) in the electrical conductivity was observed among all the honey samples. Terrab et al.[13] stated that electrical conductivity depend on botanical origin of honey along with other factors like mineral content, organic acids, some complex sugars, proteins and polyols. According to the Codex Alimentarius [2] electrical conductivity values for floral honey should have value less than $0.8 \mathrm{mS} \mathrm{cm}$, whereas honeydew should have values greater than $0.8 \mathrm{mS}$ $\mathrm{cm}^{-1}$. All honey samples evaluated had electrical conductivity values below $0.8 \mathrm{mS} \mathrm{cm}^{-1}$ which indicates that all the samples from the different locations are of floral botanical origin. According to Bogdanov et al. [18] conductivity is good criterion for determining botanical origin of honey and it is determined today as a routine honey quality control parameter instead of the ash content. Piazza et al. [48] developed a linear model which describes the relationship between the ash content and electrical conductivity in Italian unifloral honeys as $\mathrm{C}=0.14+1.74 \mathrm{~A}$, in which $\mathrm{C}$ is the electrical conductivity in milliSiemens per $\mathrm{cm}$ and $\mathrm{A}$ is the ash content in $\mathrm{g} / 100 \mathrm{~g}$.

Sugar content: The total reducing sugar and sucrose contents in thehoney samples varied from $74.30 \pm 0.03$ to $82.30 \pm 0.04 \%$ and from $3.58 \pm 0.02$ to $4.71 \pm 0.02 \%$, respectively. Significant difference $(p \leq 0.05)$ was not observed among all the honey samples in both the total reducing sugar and sucrose contents. The total reducing sugar of the honey samples were above $65 \%$, the minimum limit set by EEC regulations [49] for reducing sugars. The mean percentages of sucrose of the studied honey were all below $5 \%$ which is the maximum limit proposed by FAO/WHO standards of honey [50]. The findings of this study are further authenticated by Codex Alimentarious [2] given the fact that the range of non-reducing sugar in honey is 1.15 to $12 \%$. Besides, these results are also in agreement with those of Kamal et al. [24] who indicated a range of 1.115 to $12.135 \%$ in honey varieties.

Hydroxymethylfufural(HMF): Hydroxymethylfurfural (HMF) content is used as an indicator of the purity and quality of honey because fresh honeys do not contain HMF [36]. High level of HMF in honey shows overheating, improper storage conditions and aged honey [36]. The overall average HMF value of honey samples analyzed in the present study ranges from $10.51 \pm 0.04$ to $14.31 \pm 0.02 \mathrm{mg} \mathrm{kg}$ 1 . These values are within the range of HMF values (3.0-18.3 $\mathrm{mg} \mathrm{kg}$ ) for 27 analyzed honey samples in Spain. No significant difference $(\mathrm{p} \leq 0.05)$ was observed among the honey samples. No honey sample in this experiment exceeded the international regulation which sets a level of maximum HMF to $40 \mathrm{mg} \mathrm{kg}^{-1}$ [2]. Other studies on honey from various countries have reported the HMF content value: Argentinean honey $14.8 \mathrm{mg} \mathrm{kg}^{-1}$ [33], Turkish honey $7.26 \mathrm{mg}$ $\mathrm{kg}^{-1}$ [51], Portugal honey $6.5 \mathrm{mg} \mathrm{kg}^{-1}$ [52].

Diastase activity:The diastase activity of the analyzed honey samples ranges from $23.20 \pm 0.02$ to $26.46 \pm 0.02$ units on the Gothe scale. These values are within the range of diastase activities $\left(10-29 \mathrm{G}^{\circ}\right)$ for 27 analyzed honey samples in Spain. No significant difference $(\mathrm{p} \leq 0.05)$ was observed among the honey samples. The diastase activity is an acceptable parameter in evaluating the freshness of honey. Diastase activity is a quality factor influenced byhoney storage and heating. Although there is a largenatural variation of this parameter in honey, a standard of a minimum value of 8 on the Gothe scale, has proven to beuseful [53]. From this point of view theanalyzed samples were fresh with mean values ranging from $23.20 \pm 0.02$ to $26.46 \pm 0.02$ units on the Gothe scale.

Protein content: The protein content can be attributed to the presence ofdifferent types of enzymes and other derived products thatwere introduced by the bees from the flower nectar. Theprotein content of tested litchi honey samples was found in the range $0.74 \pm 0.01$ to $0.85 \pm 0.01 \%$. The same protein levelshave also been reported in Algerian honey samples [45]; whereas for honey samples from India, the content wasreported to be lower [54]. The protein content can be attributedto the presence of different types of enzymes and other derivedproducts that were introduced by the bees from the flowernectar. Protein levels in honey are dependent on the type offlora on which the bees forage [50]. No significant difference $(p \leq 0.05)$ was observed among the honey samples.

\section{Conclusion}

This study shows the variability of some quality characteristics of honey samples from the different locations of Taraba State. The results obtained have demonstrated that the honey samples obtained from different locations of Taraba State can be compared favorably well with other samples from other geographical locations. The honeys were mostly of good quality when compared with several international standardsof honey specifications. However, the difference in composition and quality parameters of the honey samples may also be influenced by factors such as differences in climatic conditions, soil characteristics, honey bee specie, activity of the bee, environmental temperature, harvesting methods and storage conditions.

\section{References}

[1] Roubik, D. W. (1989). Ecology and Natural History of Tropical Bees. New York: Cambrige University Press, pp. 195-210. 
[2] Codex Alimentarius (2001). Draft revised standard for honey (at step 10 of the codex procedure). Codex Alimentarius Commission, FAO, Rome Alinorm, 25: 19 - 26.

[3] James, O. O., Mesubi, M. A., Usman, L. A., Yeye, S. O. and Ajanaku, K. O. (2009). Physical characteristics of some honey samples from North-Central Nigeria. International Journal of Physical Sciences, 4: 464 -470.

[4] Funmilola, O. O., Oluwatosin, A. I. and Olayemi, B. O. (2014). Physicochemical properties of honey samples from Ondo state, Nigeria, and their bioactivity against spoilage and pathogenic organisms. Journal of Food, Agriculture and Environment, 12(3\&4): 104 - 107.

[5] Gheldof, N. and Engeseth, N. J. (2002). Antioxidant capacity of honeys from various floral sources based on the determination of oxygen radical absorbance capacity and inhibition of in vitro lipoprotein oxidation in human serum samples. Journal of Agricultural and Food Chemistry, 50(10): 3050-3055.

[6] Sanz, M. L., Sanz, J. and Martinez, C. L. (2004). Presence of some cyclitols in honey. Journal of Food Chemistry, (84): 133-135.

[7] Kumar, A., Gill, J. P. S., Bedi, J. S., Manav, M., Ansari, M. J. and Walia, G. S. (2018). Sensorial and physicochemical analysis of Indian honeys for assessment of quality and floral origins. Food Research International, 108: 571-583.

[8] Omafuvbe, B. O. and Akanbi, O. O. (2009). Microbiological and physico-chemical properties of some commercial Nigerian honey. African Journal of Microbiology Research, 3: 891-896.

[9] Amril, A. and Ladjama, A. (2013). Physicochemical characterization of some multifloral honeys from honeybees Apismelliferacollected in the Algerian northeast. African Journal of Food Science, 7(7): 168 - 173.

[10] Escuredo, O., Seijo, M. and Fernandez-Gonzalez, M. (2011). Descriptive analysis of rubus honey from the north-west ofSpain. International Journal of Food Science and Technology, 46: 2329 - 2336.

[11] Al-Habsi, N. and Niranjan, K. (2012). Effect of high hydrostatic pressure on antimicrobial activity and quality of manuka honey. Food Chemistry, 135: 1448 - 1454.

[12] Eleazu, C. O., Iroaganachi, M. A., Eleazu, K. C. and Okoronkwo, J. O. (2013). Determination of the physicochemical composition, microbial quality and free radical scavenging activities of some commercially sold honey samples in Aba, Nigeria: The effect of varying colours. International Journal of Biomedical Research, 04(01): 32-41.

[13] Terrab, A., Gonzalez, A. G. Diez, M. J. and Francisco, J. H. (2003). Characterization of Moroccan unifloral honeys using multivariate analysis. European Food Research and Technology, 218(1): 88-95.

[14] Atrouse, O. M., Oran, S. A. and Al-Abbadi, S. Y. (2004). Chemical analysis and identification of pollen grains from different Jordanian honey samples. International Journal of Food Science and Technology, 39: 413-417.

[15] Lawal, R. A, Lawal, A. K. and Adekalu, J. B. (2009). Physicochemical Studies on Adulteration of Honey in Nigeria. Pakistan Journal of Biological Sciences, 12(15): 1080-1084.
[16] Rahman, K., Hussain, A., Ullah, S. and Zai, I. U. M. (2013). Phytochemical Analysis and Chemical Composition of Different Branded and Unbranded Honey Samples. International Journal of Microbiological Research, 4 (2): 132-137.

[17] Mato, I., Huidobro, J. F., Lozano, J. S. and Sancho, M. T. (2003). Significance of no-aromatic organic acids in honey. Journal of Food Protection, 66(12): 2371-2376.

[18] Bogdanov, S., Haldimann, M., Luginbuhl, W. and Gallmann, P. (2007). Minerals in honey: environmental, geographical and botanical aspects. Journal of Apicultural Research, 46(4): 269-275.

[19] Molan, P. C. (2001). Why honey is effective as a medicine. The scientific explanation of its effects. Bee World, 82(1): 22-40.

[20] AOAC (2005). Official Methods of Analysis of the Association of Analytical Chemists International, 18th edition, Gathersburg, MD U.S.A Official methods. 2200 pp.

[21] Downey, G., Hussey, K., Kelly, J. D., Walshe, T. F. and Martin, P. G. (2005). Preliminary contribution to the characterisation of artisanal honey produced on the island of Ireland by palynological and physico-chemical data. Food Chemistry, 91(2): 347-354.

[22] Bertoncelj, J., Doberšek, U., Jamnik, M. and Golob, T. (2007). Evaluation of the phenolic content, antioxidant activity and colour of Slovenian honey. Food Chemistry, 105(2): 822-828.

[23] Terrab, A., Gonzalez-Miret, L. and Heredia, F. J. (2004). Colour characterisation of thyme and avocado honeys by diffuse reflectance spectrophotometry and spectroradiometry. European Food Research and Technology, 218(5): 488-492.

[24] Kamal, A., Raza, S., Rashid, N., Hameed, T., Gilani, M., Qureshi, M. A. and Nasim, K. (2002). Comparative study of honey collected from different flora of Pakistan. Journal of Biological Sciences, 2(9): 626-627.

[25] Ouchemoukh, S., Louaileche, H. and Schweitzer, P. (2007). Physicochemical characteristics and pollen spectrum of some Algerian honeys. Food Control, 18(1): 52-58.

[26] Basavarajappa, S., Raghunandan, K. S., and Hegde, S. N. (2011). Physico-biochemical analysis of multifloral honey of Apisdorsata Fab.(Hymenoptera: Apidae) in Southern Karnataka, India. Current Biotica, 5(2): 144-156.

[27] Bath, K. P. and Singh, N. (1997). Quality Evaluation of Different types of Indian honey. Food Chemistry, 58(1 - 2): $129-133$.

[28] EU (2001). European Union Council: Council Directive (2001)/110/EC of 20 December 2001 relating to honey. Official Journal of the European Community, 10: 47-52.

[29] Adebiyi, F. M., Akpan, I., Obiajunwa, E. I. and Olaniyi, H. B. (2004). Chemical/physical characterization of Nigeria honey. Pakistan Journal of Nutrition, 3(5): 278 - 281.

[30] Oladipupo, M. D. and Isah, M. C. (2009). Physical and Chemical properties of some Nigerian honey collected in Kaduna State. The Nigerian Journal of Research and Production, 15(2): 1-7.

[31] Gebremedhin, G., Tadesse, G. and Kebede, E. (2013). Physiochemical characteristics of honey obtained from traditional and modern hive production systems in Tigray region, Northern Ethiopia. Momona Ethiopian Journal of Science, 5: 115-128. 
[32] Zamora, M. C., Chirife, J. and Roldan, D. (2006). On the nature of the relationship between water activity and\% moisture in honey. Food Control, 17(8): 642-647.

[33] Finola, M. S., Lasagno, M. C. and Marioli, J. M. (2007). Microbiological and chemical characterization of honeys from central Argentina. Food Chemistry, 100(4): 1649-1653.

[34] [Gobessa, S., Seifu, E. and Bezabih, A. (2012). Physicochemical properties of honey produced in the Homesha district of Western Ethiopia. Journal of Apicultural Science, 56: 33-40.

[35] FAO (2009). A guide to the services provided by bees and the sustainable harvesting, processing and marketing of their products. Rome, Italy.

[36] Gomes, S., Dias, L. G., Moreira, L. L., Rodrigues, P. and Estevinho, L. (2010). Physicochemical, microbiological and antimicrobial properties of commercial honeys from Portugal. Food and Chemical Toxicology, 48: 544-548.

[37] Azenedo, L., Azeredo, M., De Souza, S. and Dautra, L. (2003). Protein content and physiochemical properties in honey samples of ApisMellifera of different floral origins. Food Chemistry, 80(2): 249 - 254.

[38] Viuda-Martos, M., Ruiz-Navajas, Y., Zaldivar-Cruz, J., Kuri, V., Juana Fernandez-Lopez. J., Carbonell-Barrachina, A. and Perez-Alvarez, J. (2010). Aroma profile and physico-chemical properties of artisanal honey from Tabasco, Mexico. International Journal of Food Science and Technology, 45: $1111-1118$.

[39] Nyau, V., Mwanza, P. and Moonga, B. (2013). Physicochemical qualities of honey harvested from different beehive types in zambia. African Journal of Food, Agriculture, Nutrition and Development, 13(2): 7415 - 7427.

[40] Marchini, L. C., Moretti, A. C., Otsuki, I. P. and Sodre, G.(2007). Physicochemical composition of Apismelliferahoney samples from Sao Paulo state, Brazil. QuimicaNova, 30: 1653-1657.

[41] Nanda, V., Sarkar, B. C., Sharma, H. K. and Bawa, A. S. (2003). Physico-chemical properties and estimation of mineral content in honey produced from different plants in Northern India. Journal of Food Composition and Analysis, 16: 613619.

[42] Terrab, A., Diez, M. J. and Heredia, F. J. (2002). Characterisation of Moroccan unifloral honeys by their physicochemical characteristics. Food Chemistry, 79: 373379 .

[43] Cantarelli, M. A., Pellerano, R. G., Marchevsky, E. J., Camina, J. M. (2008). Quality of honey from Argentina: study of chemical composition and trace elements. The Journal of the Argentine Chemical Society, 96(1-2): 33 - 41.

[44] Buba, F., Gidado, A. and Shugaba, A. (2013). Physicochemical and Microbiological Properties of Honey from North East Nigeria. Biochemistry and Analytical Biochemistry, 2(4): 1-7.

[45] Silva, L. R., Videira, R., Monteiro, A. P., Valentao, P. and Andrade, P. B. (2009). Honey from Luso region (Portugal): Physicochemical characteristics and mineral contents. Microchemical Journal, 93: 73-77.

[46] Zappala, M., Fallico, B., Arena, E. and Verzera, A. (2005). Methods for the determination of hydroxymethylfurfural (HMF) in honey: a comparison. Food Control, 16: 273-277.

[47] Smanalieva, J. and Senge, B.(2009). Analytical and rheological investigations into selected unifloral German honey. European Food Research and Technology, 229: 107113.

[48] Piazza, M. G., Accorti, M. and Persano-Oddo, L. (1991). Electrical conductivity, ash, colour and specific rotatory power in Italian unifloral honeys. Apicoltura, 7: 51-63.

[49] EEC (1974). Council directive of 22 July 1974 on the harmonization of the laws of the member states relating to honey. Official Journal of European Communities, L221: 1014.

[50] Meda, A., Lamien, C. E., Romito, M., Millogo, J. andNacoulma, O. G. (2005). Determination of the total phenolic, flavonoid andproline contents in Burkina Fasan honey, as well as theirradical scavenging activiity. Food Chemistry, 91:571-577.

[51] Furkan Y. M. and Gumus, T. (2010). Some physico - chemical characteristics of honeys produced from sunflower plant (Helianthus annuus L.). International journal of food science and technology, 45 (4): 707-712.

[52] Feas, X., Pires, J., Estevinho, M. L., Iglesias, A. and DeAraujo, J. P. P. (2010). Palynological and physicochemical data characterisation of honeys produced in the Entre - Douro e Minho region of Portugal. International journal of food science and technology, 45 (6): 1255-1262.

[53] Bogdanov, S., Lullman, C., Martin, P., Von der Ohe, W., Russman, H. and Vorwohl, G. (1999). Honey quality and international regulatory standards: Review by the International Honey Commission. Mitteilungenaus Leben smitte lunter suchun gund Hygiene, 90:108-125.

[54] Saxena, S., Gautam, S. and Sharma, A. (2010). Physical, biochemical and antioxidant properties of some Indian honeys. Food Chemistry, 118: 391-397. 